\title{
MESOTRIONE - A NEW HERBICIDE FOR WEED CONTROL IN MAIZE
}

\author{
T.K. JAMES ${ }^{1}$, A. RAHMAN ${ }^{1}$ and J. HICKING ${ }^{2}$ \\ ${ }^{1}$ AgResearch, Ruakura Research Centre, Private Bag 3123, Hamilton, \\ New Zealand \\ ${ }^{2}$ Orion Crop Protection Ltd, P.O Box 100570, Auckland, New Zealand \\ Corresponding author: trevor.james@agresearch.co.nz
}

\begin{abstract}
Six field trials were conducted over three growing seasons to evaluate both pre-and post-emergence applications of the recently developed herbicide mesotrione, for weed control in maize. As a pre-emergence treatment it provided excellent control of broadleaf weeds ( $>99 \%$ reduction in dry matter) but was poor on grass weeds (ca $80 \%$ reduction). However, its combination with atrazine, s-metolachlor or acetochlor provided $>93 \%$ reduction in grass and broadleaf weed dry matter. Applications of mesotrione post-emergence were very effective on broadleaf weeds (>94\%) but less so on grass weeds (ca 85\%) although several adjuvant combinations improved the efficacy against annual grass weeds. A number of herbicide combinations were demonstrated to be effective for postemergence weed control. Mesotrione did not cause any apparent damage to maize crops in any trial and grain yields were not significantly different from the standard treatments. Recommended rates for post-emergence use of mesotrione will be 72-96 g/ha depending on soil type.
\end{abstract}

Keywords: mesotrione, herbicides, maize weeds, pre-emergence, postemergence, residual activity.

\section{INTRODUCTION}

Mesotrione, a triketone herbicide, is the result of chemical optimisation of a phytotoxin isolated from the bottlebrush (Callistemon citrinus). Its mode of action is to inhibit the enzyme 4-hydroxyphenolpyruvate dioxygenase (HPPD). This leads to a reduction of carotenoids and causes the bleaching symptoms (albinism) that are typical of this mode of action (Mitchell et al. 2001). There are no other herbicides of this type or with this mode of action available in New Zealand. Mesotrione has an excellent environmental profile with extensive and rapid microbial breakdown (Wichert et al. 1999). In soils of similar pH to New Zealand soils but with lower organic carbon contents, soil half-life ranged from 2-14 days. Mesotrione has been shown to be effective for both pre- and post-emergence control of weeds in maize (Sutton et al. 1999; Armel et al. 2003b). However, as it is a weak acid mesotrione has been found to be highly adsorbed by soil organic matter in acid soils, thus requiring higher rates when applied pre-emergence in these environments (Wichert et al. 1999). It can be used in both conventional and no-till maize as well as to control glyphosate tolerant weeds in glyphosate-resistant maize (Armel et al. 2003a, c).

Mesotrione has been introduced to New Zealand as a $480 \mathrm{~g} /$ litre soluble concentrate formulation $\left(\right.$ Callisto $^{\circledR}$ ) and is pending registration for control of weeds in maize. This paper reports on a series of development trials carried out to determine optimum use rates and application timings for New Zealand conditions. 


\section{MATERIALS AND METHODS}

Mesotrione was evaluated in six field trials for both pre- and post-emergence weed control in maize from 2001 to 2005. It was used alone and in combination with other herbicides and with different adjuvants. The trials were at various locations in the Waikato region of New Zealand. Some experimental details are summarised in Table 1 and further specific information about individual trials is given below. Details on the herbicide formulations and adjuvant chemistry are given in the appendix.

\section{TABLE 1: Experimental details for Trials 1-6.}

\begin{tabular}{lllrll}
\hline \multicolumn{2}{l}{$\begin{array}{l}\text { Planting } \\
\text { Trial date }\end{array}$} & $\begin{array}{l}\text { Application } \\
\text { timing }\end{array}$ & $\begin{array}{l}\text { Spraying } \\
\text { date }\end{array}$ & Weather conditions & Rainfall \\
\hline 1 & 23.10 .01 & Pre-emerg & 25.10 .01 & $13^{\circ} \mathrm{C}$, moist soil & $35 \mathrm{~mm}$ within 7 days \\
2 & 15.11 .02 & Pre- and & 20.11 .02 & $13^{\circ} \mathrm{C}, 80 \%$ cloud cover & $7 \mathrm{~mm}$ within 7 days \\
& & Post-emerg & 23.12 .02 & $20^{\circ} \mathrm{C}$, sunny & 0 for 2 days \\
3 & 23.10 .02 & Post-emerg & 27.11 .02 & $14^{\circ} \mathrm{C}$, overcast & $5.5 \mathrm{~mm}$ within $24 \mathrm{~h}$ \\
4 & 23.10 .04 & Pre-emerg & 27.10 .04 & $17^{\circ} \mathrm{C}$, sunny, wet soil & $15 \mathrm{~mm}$ over 2 days \\
5 & 23.10 .04 & Post-emerg & 7.12 .04 & $20^{\circ} \mathrm{C}, 20 \%$ cloud cover & 0 for 1 day \\
6 & 13.09 .04 & Post-emerg & 18.11 .04 & $19^{\circ} \mathrm{C}, 50 \%$ cloud cover & 0 for 4 days \\
\hline
\end{tabular}

The soil type for all trials was a Horotiu silt loam, except for Trial 2, which was on a Hamilton clay loam. The maize cultivar planted was Pioneer $36 \mathrm{H} 36$ in Trials 1-3 and Pioneer 36B08 in Trials 4-6. The main weeds present in the untreated plots in all trials included willow weed (Polygonum persicaria), fathen (Chenopodium album), black nightshade (Solanum nigrum), summer grass (Digitaria sanguinalis), twin cress (Coronopus didymus) and smooth witchgrass (Panicum dichotomiflorum). Trial 1 also had redroot (Amaranthus spp.). Additional weed species in Trial 2 included barnyard grass (Echinochloa crus-galli), and most weeds were up to $300 \mathrm{~mm}$ tall at the time of treatment. Trial 3 included spurrey (Spergula arvensis) but no barnyard grass. Trials 4 and 5 also had spurrey as well as thorn apple (Datura stramonium), barnyard grass, Mercer grass (Paspalum distichum), broadleaf dock (Rumex obtusifolius), apple of Peru (Nicandra physalodes) and pink bindweed (Calystegia sepium). Both the maize plants and weeds were up to $400 \mathrm{~mm}$ tall at application in Trial 5. The weed flora in Trial 6 was limited mainly to willow weed and fathen with some broadleaf dock, couch (Elytrigia repens), spurrey, thorn apple, summer grass and smooth witchgrass present.

The trials were of complete, randomised block design with four replicates and individual plot sizes of $3 \mathrm{~m} \times 10-15 \mathrm{~m}$. Each plot contained four rows of maize planted at $750 \mathrm{~mm}$ row spacing. All herbicide treatments were applied with a precision $\mathrm{CO}_{2}$-powered backpack sprayer delivering 200 litres/ha at $210 \mathrm{kPa}$ using four TeeJet 11003 nozzles at $750 \mathrm{~mm}$ spacing. For the post-emergence treatments the nozzles were centred down the rows to maximise herbicide deposition on the weeds and minimise it on the maize plants.

Weed control scores are a visual assessment combining weed abundance and weed health where 0 is no effect and 100 is complete control. Weed dry matter was determined by cutting and collecting weeds at ground level in two, randomly placed, $0.1 \mathrm{~m}^{2}$ quadrats from each plot. The collected weeds were separated into grass and broadleaf species, dried and weighed. Maize grain yields were determined by collecting 50 cobs from the two centre rows of each plot. The cobs were shelled, dried and weighed. Grain yields are reported in tonnes/ha at $14 \%$ moisture content. All data were subjected to analysis of variance (ANOVA) to separate the means. The arithmetic means and least significant difference (LSD) are presented for observational data and for grain yields. When required, weed dry matter data were $\log _{10}$ transformed prior to analysis. For these data, the arithmetic means for the untransformed data are presented along with letters indicating significant differences $(\mathrm{P}<0.05)$ as determined for the means of the transformed data. 


\section{RESULTS AND DISCUSSION}

In Trial 1 mesotrione alone applied pre-emergence stopped all weeds from germinating for about the first 4 weeks but after this some grass weeds started to emerge. This is reflected in the dry matter weights for grass weeds (Table 2). Broadleaf weed dry matter was reduced by more than $99 \%$ for the whole season. When combined with pre-emergence grass killing herbicides, s-metolachlor or acetochlor, grass weed dry matter was reduced to a similar degree for the entire season. The standard treatments of s-metolachlor+atrazine and acetochlor+atrazine also provided season-long control of all the weeds. For all the herbicide treatments maize yields were increased by at least $70 \%$ but there were no significant differences between them.

TABLE 2: Visual weed control $(\%)$ on 12.12.01, weed dry matter (kg/ha) on 23.1.02 and maize grain yields (t/ha) on 14.5 .02 for pre-emergence application of mesotrione and other herbicides in Trial 1.

\begin{tabular}{|c|c|c|c|c|c|c|c|}
\hline \multirow{3}{*}{$\frac{\text { Treatment }}{\text { untreated }}$} & \multirow{3}{*}{$\begin{array}{c}\begin{array}{c}\text { Rate } \\
\text { (g ai/ha) }\end{array} \\
-\end{array}$} & \multirow{3}{*}{$\begin{array}{c}\% \text { weed } \\
\text { control }\end{array}$} & \multicolumn{4}{|c|}{ Weed dry matter } & \multirow{3}{*}{ 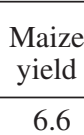 } \\
\hline & & & \multicolumn{2}{|c|}{ Grass } & \multicolumn{2}{|c|}{ Broadleaf } & \\
\hline & & & 253 & $a^{1}$ & 4599 & $a^{1}$ & \\
\hline mesotrione & 180 & 91 & 55 & $\mathrm{bc}$ & 3 & $\mathrm{c}$ & 11.9 \\
\hline mesotrione & 240 & 91 & 41 & $\mathrm{bc}$ & 3 & $\mathrm{c}$ & 11.7 \\
\hline mesotrione & 480 & 93 & 45 & $\mathrm{c}$ & 2 & $\mathrm{c}$ & 12.9 \\
\hline s-metolachlor+mesotrione & $1000+120$ & 98 & 1 & $\mathrm{~d}$ & 4 & $\mathrm{c}$ & 12.0 \\
\hline s-metolachlor+mesotrione & $2000+240$ & 100 & 0 & $\mathrm{e}$ & 1 & $\mathrm{c}$ & 11.9 \\
\hline s-metolachlor+atrazine & $2000+1500$ & 98 & 0 & $\mathrm{e}$ & 1 & $\mathrm{c}$ & 11.3 \\
\hline acetochlor+atrazine & $2520+912$ & 99 & 1 & $\mathrm{~d}$ & 2 & $\mathrm{c}$ & 12.7 \\
\hline acetochlor+mesotrione & $1600+120$ & 99 & 4 & $\mathrm{~d}$ & 2 & $\mathrm{c}$ & 11.2 \\
\hline acetochlor + mesotrione & $2500+240$ & 100 & 0 & $\mathrm{e}$ & 1 & $\mathrm{c}$ & 12.1 \\
\hline LSD $(\mathrm{P}<0.05)$ & & 2.5 & & & & & 2.30 \\
\hline
\end{tabular}

${ }^{1}$ Data followed by the same letter are not significantly different $(\mathrm{P}<0.05)$.

In the following year (Trial 2) mesotrione was evaluated for both pre- and postemergence use. For pre-emergence applications, mesotrione was used at lower rates than the previous year (Table 3). When used alone or in combination with s-metolachlor, it failed to give adequate control of the broadleaf weeds, especially thorn apple, fathen and redroot, but when used in combination with acetochlor, weed control was improved considerably. Due to bad weather the post-emergence treatments could not be applied until 23 December 2002 and some of the weeds were larger than the 2-4 leaf stage that is recommended. However, the $150 \mathrm{~g} / \mathrm{ha}$ mesotrione treatment still significantly reduced grass and broadleaf dry matter to give similar levels of control to both the dicamba and acetochlor plus atrazine treatments (Table 3 ). The atrazine-resistant fathen was not well controlled by the s-metolachlor plus atrazine treatment.

In the post-emergence trial (Trial 3), the grass weeds present were not well controlled by the mesotrione-alone treatments (Table 4). The addition of atrazine to mesotrione significantly improved the control of grass weeds. Summer grass and crowfoot grass (Eleusine indica) were more susceptible to mesotrione than smooth witchgrass. Nicosulfuron plus Activator also gave large reductions in grass weed dry matter. With the exception of wild portulaca (Portulaca oleracea), all the broadleaf weeds present were significantly reduced by mesotrione. Portulaca was well controlled by atrazine, dicamba and nicosulfuron. Twin cress and spurrey were only partially controlled by dicamba. 
TABLE 3: Visual weed control $(\%)$ on 16.12 .02 , weed dry matter $(\mathrm{kg} / \mathrm{ha})$ on 6.3 .03 and maize grain yields (t/ha) on $\mathbf{1 . 6 . 0 3}$ for pre- and post emergence applications of mesotrione and other herbicides in Trial 2.

\begin{tabular}{|c|c|c|c|c|c|}
\hline \multirow[b]{2}{*}{ Treatment } & \multirow{2}{*}{$\begin{array}{c}\text { Rate } \\
\text { (g ai/ha) }\end{array}$} & \multirow{2}{*}{$\begin{array}{l}\% \text { weed } \\
\text { control }\end{array}$} & \multicolumn{2}{|c|}{ Weed dry matter } & \multirow{2}{*}{$\begin{array}{l}\text { Maize } \\
\text { yield }\end{array}$} \\
\hline & & & Grass & Broadleaf & \\
\hline untreated control & - & 0 & $483 \mathrm{a}^{1}$ & $1885 \mathrm{a}^{1}$ & 4.97 \\
\hline mesotrione & 150 & 35 & $-{ }^{2}$ & - & - \\
\hline s-metolachlor+mesotrione & $1920+75$ & 63 & - & - & - \\
\hline s-metolachlor+mesotrione & $1920+150$ & 73 & - & - & - \\
\hline s-metolachlor+atrazine & $1920+1500$ & 68 & $11 \mathrm{c}$ & $757 \mathrm{ab}$ & 7.95 \\
\hline acetochlor+mesotrione & $2520+75$ & 86 & $5 \mathrm{c}$ & $130 \mathrm{bc}$ & 7.79 \\
\hline acetochlor+mesotrione & $2520+150$ & 90 & $4 \mathrm{c}$ & $22 \mathrm{~cd}$ & 7.47 \\
\hline acetochlor+atrazine & $2520+1500$ & 89 & $7 \mathrm{c}$ & 203 bc & 8.62 \\
\hline mesotrione $^{3}$ & 75 & & $72 \mathrm{ab}$ & $106 \mathrm{~cd}$ & 7.55 \\
\hline mesotrione $^{3}$ & 150 & - & $71 \mathrm{bc}$ & $3 \mathrm{e}$ & 6.95 \\
\hline dicamba $^{3}$ & 400 & - & $287 \mathrm{ab}$ & $0 \mathrm{e}$ & 7.34 \\
\hline LSD $(\mathrm{P}<0.05)$ & & 10.6 & & & 1.130 \\
\hline
\end{tabular}

${ }^{1}$ Data followed by the same letter are not significantly different $(\mathrm{P}<0.05)$.

${ }^{2}$ Treatments abandoned due to lack of weed control.

${ }^{3}$ Treatments applied post-emergence.

TABLE 4: Visual weed control $(\%)$ on 13.12 .02 , weed dry matter $(\mathrm{kg} / \mathrm{ha})$ on 22.1.03 and maize grain yields (t/ha) on 28.5.03 for post-emergence applications of mesotrione and other herbicides in Trial 3.

\begin{tabular}{|c|c|c|c|c|c|}
\hline \multirow[b]{2}{*}{ Treatment $^{1}$} & \multirow{2}{*}{$\begin{array}{c}\text { Rate } \\
\text { (g ai/ha) }\end{array}$} & \multirow{2}{*}{$\begin{array}{l}\% \text { weed } \\
\text { control }\end{array}$} & \multicolumn{2}{|c|}{ Weed dry matter } & \multirow{2}{*}{$\begin{array}{c}\text { Maize } \\
\text { yield }\end{array}$} \\
\hline & & & Grass & Broadleaf & \\
\hline untreated & - & 0 & $185 \mathrm{a}^{2}$ & $1606 \mathrm{a}^{2}$ & 5.34 \\
\hline mesotrione & 75 & 67 & 249 a & $4 \mathrm{~d}$ & 8.38 \\
\hline mesotrione & 100 & 73 & 276 a & $4 \mathrm{~d}$ & 8.71 \\
\hline mesotrione & 200 & 80 & $103 \mathrm{ab}$ & $0 \mathrm{~d}$ & 7.89 \\
\hline mesotrione+atrazine & $100+750$ & 85 & $94 \mathrm{bc}$ & $0 \mathrm{~d}$ & 9.28 \\
\hline dicamba & 400 & 55 & 375 a & $185 \mathrm{~b}$ & 8.16 \\
\hline nicosulfuron+Activator ${ }^{3}$ & $60+0.5 \%$ & 93 & $15 \mathrm{c}$ & & 8.85 \\
\hline LSD $(\mathrm{P}<0.05)$ & & 10.9 & & & 1.57 \\
\hline
\end{tabular}

${ }^{1}$ All mesotrione treatments were applied with the surfactant Citowett at $0.25 \%$.

${ }^{2}$ Data followed by the same letter are not significantly different $(\mathrm{P}<0.05)$.

${ }^{3}$ For details on the Activator adjuvant see the appendix.

In the 2004/05 season (Trial 4) mesotrione was used in combination with several other herbicides to improve pre-emergence control of grass weeds (Table 5). The addition of either s-metolachlor, acetochlor or acetochlor+atrazine to mesotrione significantly improved control of grass weeds. They also provided excellent control of the atrazineresistant fathen which was not well controlled by the acetochlor+atrazine mixture. When used alone, mesotrione gave excellent control of broadleaf weeds initially but its residual activity was not sufficient as a pre-emergence treatment for season-long control and after 4-6 weeks some broadleaf weeds started to grow in the treated plots. 
TABLE 5: Visual weed control $(\%)$ on 29.11.04 and 12.01.05, weed dry matter (kg/ha) on 25.1.05 and maize grain yields (t/ha) on 9.5 .05 for pre-emergence applications of mesotrione and other herbicides in Trial 4.

\begin{tabular}{|c|c|c|c|c|c|c|}
\hline \multirow[b]{2}{*}{ Treatment } & \multirow{2}{*}{$\begin{array}{c}\text { Rate } \\
\text { (g ai/ha) }\end{array}$} & \multicolumn{2}{|c|}{$\%$ weed control } & \multicolumn{2}{|c|}{ Dry matter } & \multirow{2}{*}{$\begin{array}{l}\text { Maize } \\
\text { f yield }\end{array}$} \\
\hline & & 29.11 & 12.01 & Grasses & Broadleaf & \\
\hline untreated control & & 0 & 0 & $460 \mathrm{a}$ & $3695 \mathrm{a}$ & 6.07 \\
\hline mesotrione & 168 & 96 & 80 & $91 \mathrm{~b}^{1}$ & $41 \mathrm{c}^{1}$ & 8.20 \\
\hline mesotrione & 216 & 96 & 80 & $126 \mathrm{~b}$ & $16 \mathrm{~cd}$ & 8.83 \\
\hline mesot $^{2}+$ acetochlor+atrazine & $168+1764+1050$ & 50100 & 100 & $0 \mathrm{c}$ & $0 \mathrm{~d}$ & 9.10 \\
\hline mesot+acetochlor+atrazine & $216+2520+1500$ & 00100 & 98 & $1 \mathrm{c}$ & $1 \mathrm{~d}$ & 10.13 \\
\hline acetochlor+atrazine & $1764+1050$ & 98 & 94 & $2 \mathrm{c}$ & $62 \mathrm{c}$ & 8.92 \\
\hline $\mathrm{ac}$ & $2520+1500$ & 99 & 89 & $0 \mathrm{c}$ & $55 \mathrm{c}$ & 9.14 \\
\hline lachlor & $168+1248$ & 99 & 99 & $0 \mathrm{c}$ & $0 \mathrm{~d}$ & 9.29 \\
\hline etolachlor & $216+1920$ & 99 & 100 & $0 \mathrm{c}$ & $0 \mathrm{~d}$ & 9.73 \\
\hline chlor & 1920 & 92 & 80 & $1 \mathrm{c}$ & $869 \mathrm{c}$ & 8.38 \\
\hline -aceto & $168+1848$ & 99 & 99 & $0 \mathrm{c}$ & $0 \mathrm{~d}$ & 8.36 \\
\hline mesotrione+acetochlor & $216+2520$ & 100 & 100 & $0 \mathrm{c}$ & $0 \mathrm{~d}$ & 8.89 \\
\hline acetochlor & 2520 & 98 & 94 & $2 \mathrm{c}$ & $14 \mathrm{~cd}$ & 9.34 \\
\hline LSD $(\mathrm{P}<0.05)$ & & 3.5 & 7.9 & & & 1.065 \\
\hline
\end{tabular}

${ }^{1}$ Data followed by the same letter are not significantly different $(\mathrm{P}<0.05)$.

${ }^{2}$ mesot=mesotrione.

Adverse weather conditions delayed the application of post-emergence treatments in Trial 5 for about 2 weeks. As a result the weeds were larger and the levels of weed control achieved were not optimal in many of the treatments (Table 6). However, the failure of some treatments also reflected the lack of efficacy against certain weeds present at the time of application. When used alone, atrazine did not control grass weeds or atrazineresistant-fathen but controlled all the other broadleaf weeds. Nicosulfuron had good efficacy on both grass and broadleaf weeds except for scrambling speedwell (Veronica persica) and broad-leaved dock. Dicamba did not control the grass weeds, speedwell, spurrey, chamomile (Chamaemelum nobile), creeping buttercup (Ranunculus repens), twin cress or scrambling fumitory (Fumaria muralis) but gave excellent control of fathen, willow weed, redroot and broad-leaved dock. Clopyralid also did not control grass weeds as well as many of the broadleaf weeds, including broad-leaved dock, redroot, willow weed, fathen and speedwell. Primisulfuron gave significant control of many broadleaf weeds and suppressed Mercer grass but failed to control summer grass. Mesotrione generally gave significant control of broadleaf weeds ( $>79 \%$ reduction) but was less effective on grass weeds ( $>59 \%$ reduction). Weeds that survived were docks, summer grass, smooth witchgrass, Mercer grass and speedwell.

Understandably, herbicide mixtures provided higher levels of weed control than when used alone (Table 6). Mesotrione+atrazine gave excellent control of all the broadleaf weeds present (ca 100\%) and good control of summer grass and smooth witchgrass although there were some survivors as well as new plants present at the time of the final assessment. Mesotrione+nicosulfuron followed a similar pattern for grass control but was less effective on some broadleaf weeds, in particular, broad-leaved dock and scrambling speedwell. Control of the perennial weeds pink bindweed and Mercer grass was effective with this mixture. Mesotrione+dicamba failed to adequately control summer grass and smooth witchgrass (67\% reduction) but resulted in very good control of broadleaf weeds except for black nightshade and scrambling speedwell. Mesotrione+clopyralid was similar in terms of grass weed control to mesotrione+dicamba but less effective on some broadleaf weeds, particularly redroot. Mesotrione+primisulfuron was a very effective 
TABLE 6: Visual weed control $(\%)$ on 20.12 .04 and 12.01.05, weed dry matter (kg/ha) on 25.1.05 and maize grain yields (t/ha) on 13.5 .05 for post-emergence applications of mesotrione and other herbicides in Trial 5.

\begin{tabular}{|c|c|c|c|c|c|c|}
\hline \multirow[b]{2}{*}{ Treatment } & \multirow{2}{*}{$\begin{array}{c}\text { Rate } \\
\text { (g ai/ha) }\end{array}$} & \multicolumn{2}{|c|}{$\%$ weed control } & \multicolumn{2}{|c|}{ Dry matter } & \multirow{2}{*}{$\begin{array}{l}\text { Maize } \\
\text { yield }\end{array}$} \\
\hline & & 20.12 & 12.01 & Grasses & Broadleaf & \\
\hline untreated control & - & 0 & 0 & $464 \mathrm{~b}$ & $2235 \mathrm{a}$ & 4.68 \\
\hline atrazine & 750 & 28 & 48 & $518 \mathrm{~b}^{2}$ & $1666 \mathrm{~b}^{2}$ & 6.32 \\
\hline mesotrione+atrazine & $72+500$ & 88 & 84 & $68 \mathrm{~cd}$ & $0 \mathrm{~h}$ & 7.24 \\
\hline mesotrione+atrazine & $96+750$ & 89 & 98 & $37 \mathrm{~d}$ & $0 \mathrm{~h}$ & 7.83 \\
\hline nicosulfuron & 40 & 53 & 90 & $50 \mathrm{~d}$ & $503 \mathrm{~d}$ & 7.71 \\
\hline ione+nicosulfuron & $72+20$ & 76 & 93 & $33 \mathrm{~d}$ & $60 \mathrm{fg}$ & 8.48 \\
\hline mesotrione+nicosulfuron & $96+40$ & 70 & 86 & $44 \mathrm{~d}$ & $192 \mathrm{e}^{\circ}$ & 6.75 \\
\hline dicamba & 300 & 51 & 45 & 919 a & $198 \mathrm{e}$ & 6.50 \\
\hline mesotrione+dicamba & $72+150$ & 68 & 73 & $147 \mathrm{c}$ & 122 ef & 5.95 \\
\hline mesotrione+dicamba & $96+250$ & 80 & 91 & $151 \mathrm{c}$ & 89 efg & 7.06 \\
\hline clopyralid & 300 & 41 & 28 & $469 \mathrm{~b}$ & $1129 \mathrm{c}$ & 3.71 \\
\hline mesotrione+clopyralid & $72+300$ & 78 & 92 & $191 \mathrm{c}$ & $64 \mathrm{fg}$ & 7.25 \\
\hline mesotrione+clopyralid & $96+300$ & 70 & 91 & $88 \mathrm{~cd}$ & $45 \mathrm{~g}$ & 7.15 \\
\hline primisulfuron & 30 & 47 & 70 & 828 a & 131 ef & 6.20 \\
\hline mesotrione+primisulfuron & $96+30$ & 71 & 97 & $34 \mathrm{~d}$ & $14 \mathrm{gh}$ & 7.93 \\
\hline mesotrione & 72 & 65 & 84 & $189 \mathrm{c}$ & $68 \mathrm{fg}$ & 6.77 \\
\hline mesotrione & 96 & 74 & 92 & $139 \mathrm{c}$ & 110 ef & 6.98 \\
\hline $\operatorname{LSD}(\mathrm{P}<0.05)$ & & 14.4 & 14.3 & & & 1.770 \\
\hline
\end{tabular}

${ }^{1}$ Note: All mesotrione treatments included Synoil at $1 \% \mathrm{v} / \mathrm{v}$.

${ }^{2}$ Data followed by the same letter are not significantly different $(\mathrm{P}<0.05)$.

mixture in this trial as both grass and broadleaf weeds were well controlled (>92\%). The data from this trial were also analysed for main effects and there was no significant difference between the 72 and $96 \mathrm{~g} / \mathrm{ha}$ rates of mesotrione.

In an attempt to better differentiate the herbicide treatments in Trial 6, they were applied late post-emergence to well-established weeds that would be more difficult to control. Early observations failed to detect any advantages of using an adjuvant with mesotrione (Table 7). Instead, some adjuvants appeared to significantly reduce early activity. However, the long-term effect of the adjuvants is more obvious from the weed dry matter results, which show that all adjuvants significantly increased the efficacy of mesotrione on grass weeds. In particular, activity against the annual grasses, summer grass and smooth witchgrass, was improved considerably. Mesotrione had little effect on the perennial grass couch (Elytrigia repens). As in the other trials, mesotrione was very effective on broadleaf weeds but the use of adjuvants gave no significant increase in the control of these weeds. The broadleaf weeds that remained in this trial after treatment were mostly stunted willow weed, which was not fully controlled as the large plants were flowering at the time of application.

The maize plants in all the trials showed good tolerance to mesotrione. No phytotoxic symptoms were observed in any of the mesotrione-alone or -combination treatments. Mesotrione treated plots were always among the highest yielding. Any significant reductions in grain yield were always associated with high weed dry matter yields indicating that it was the weed competition that lead to reduced yields and not herbicide phytotoxicity.

Results presented here demonstrate mesotrione to be an effective herbicide for either pre- or post-emergence control of weeds in maize. However, pre-emergence treatments 
TABLE 7: Visual weed control (\%) on 28.11.04 and 27.01.05 and weed dry matter (kg/ha) on 03.02.05 for post-emergence application of mesotrione and a range of adjuvants in Trial 6.

\begin{tabular}{|c|c|c|c|c|c|}
\hline \multirow[b]{2}{*}{ Herbicide + adjuvant } & \multirow{2}{*}{$\begin{array}{c}\text { Rate } \\
\text { (g ai/ha+\% v/v) }\end{array}$} & \multicolumn{2}{|c|}{$\%$ weed control } & \multicolumn{2}{|c|}{ Dry matter } \\
\hline & & 28.11 & 27.01 & Grasses & Broadleaf \\
\hline Untreated & & 0 & 0 & 92 & 6093 \\
\hline mesotrione + Kwickin & $96+1 \%$ & 54 & 66 & 107 & 104 \\
\hline mesotrione + Synoil & $96+0.5 \%$ & 49 & 71 & 250 & 265 \\
\hline mesotrione + Agrocer & $96+0.5 \%$ & 49 & 75 & 480 & 155 \\
\hline mesotrione + Activator & $96+0.5 \%$ & 53 & 78 & 185 & 238 \\
\hline mesotrione + Triton X-Ag & $96+0.25 \%$ & 50 & 69 & 577 & 317 \\
\hline mesotrione + Silmaxx & $96+0.1 \%$ & 45 & 80 & 102 & 597 \\
\hline mesotrione & 96 & 54 & 75 & 1106 & 89 \\
\hline LSD $(\mathrm{P}<0.05)$ & & 2.2 & 14.9 & 403.3 & 609.6 \\
\hline
\end{tabular}

will require application rates that are 2-3 times higher than post-emergence treatments. As a post-emergence herbicide mesotrione had excellent efficacy against broadleaf weeds including atrazine-resistant fathen but was weaker on grass weeds. Therefore, to ensure effective control of all weeds, mesotrione should be used either in combination with a herbicide that has more activity on grass weeds or following a pre-emergence herbicide that targets grass weeds. Controlling weeds in maize with only post-emergence treatments is often more difficult than with pre-emergence treatments for many reasons including (a) reduced efficacy, i.e. the post-emergence treatment simply not controlling the weeds so well or having a narrower spectrum of activity than pre-emergence treatments; (b) weed density, i.e. if there are too many weeds some are shaded and protected from spray deposition leading to reduced efficacy on those plants; and (c) non-optimum timing, i.e. the spray application is delayed (usually due to bad weather) and the optimum window of opportunity is missed and the target plants are larger than the 150-200 $\mathrm{mm}$ size recommended for best control. Using a combination of pre-and post-emergence herbicides overcomes many of these potential problems (Stephenson et al. 2004) and also provides the best strategy for avoiding herbicide resistance (Harrington \& James 2005).

From the results of these and other trials the recommended rates for post-emergence use of mesotrione will be 72-96 g/ha depending on soil type.

\section{APPENDIX: \\ HERBICIDE FORMULATIONS AND ADJUVANT CHEMISTRY}

Acetochlor (Sylon $840 \mathrm{~g} /$ litre), atrazine (Gesaprim $500 \mathrm{~g} /$ litre), acetochlor + atrazine (Calais $504+300 \mathrm{~g} /$ litre), clopyralid (Pirate $300 \mathrm{~g} /$ litre), dicamba (Banvel $200 \mathrm{~g} / \mathrm{litre}$ ), mesotrione (Callisto $480 \mathrm{~g} /$ litre), nicosulfuron (Amaze $40 \mathrm{~g} /$ litre), primisulfuron (Beacon $750 \mathrm{~g} / \mathrm{kg}$ ) and s-metolachlor (Dual Gold $960 \mathrm{~g} /$ litre).

Agrocer (ethoxylated fatty acids), Activator (tallow amine ethoxylate), Citowett (polyethoxylated isooctyl phenol), Kwickin (esterified canola oils), Silmaxx (polyether modified polysiloxane), Synoil (paraffininc oils + surfactant) and Triton X-Ag (octylphenol ethoxylate). 


\section{REFERENCES}

Armel GR, Wilson HP, Richardson RJ, Hines TE 2003a. Mesotrione combinations in no-till corn (Zea mays). Weed Technology 17(1): 111-116.

Armel GR, Wilson HP, Richardson RJ, Hines TE 2003b. Mesotrione, acetochlor, and atrazine for weed management in corn (Zea mays). Weed Technology 17(2): 284-290.

Armel GR, Wilson HP, Richardson RJ, Hines TE 2003c. Mesotrione alone and in mixtures with glyphosate in glyphosate-resistant corn (Zea mays). Weed Technology 17(4): 680-685.

Harrington KC, James TK 2005. Managing herbicide resistance in maize crops. In: Martin NA, Beresford RM, Harrington ed. Pesticide resistance: prevention and management strategies 2005. New Zealand Plant Protection Society Inc., Hastings, New Zealand. Pp. 147-150.

Mitchell G, Bartlett DW, Fraser TEM, Hawkes TR, Holt DC, Townson JK, Wichert RA 2001. Mesotrione: a new selective herbicide for use in maize. Pest Management Science 57: 120-128.

Stephenson DO IV, Bond JA, Walker ER, Bararpour MT, Oliver LR 2004. Evaluation of mesotrione in Mississippi Delta corn production. Weed Technology 18(4): 1111-1116.

Sutton PB, Foxon GA, Beraud J-M, Anderdon J, Wichert R 1999. Integrated weed management systems for maize using mesotrione, nicosulfuron and acetochlor. The 1999 Brighton Conference - Weeds. British Crop Protection Council. Pp. 225-230.

Wichert R, Townson JK, Bartlett DW, Foxon GA 1999. Technical review of mesotrione, a new maize herbicide. The 1999 Brighton Conference - Weeds. British Crop Protection Council. Pp. 105-110. 